\section{Inhibitory Levels of Fluoride on Mammalian Cells}

As a preliminary to more detailed investigations of the cellular effects of fluorides, growth inhibitory levels have been determined on mammalian cells. Because of the widespread concern about possible toxic effects of fluoride when used for water fluoridation, these levels are of more than theoretical interest.

Murine leukæmic lymphoblasts, $L 5178 Y$ strain, were cultured following the method of Fischer ${ }^{1}$, at $37^{\circ} \mathrm{C}$, in $16 \mathrm{~mm} \times 125 \mathrm{~mm}$ closed culture tubes, containing serial dilutions of sodium fluoride. Below a concentration of $5 \times 10^{5}$ cells $/ \mathrm{ml}$. these cells reproduce logarithmically approximately every $12 \mathrm{~h}$. Each tube contained $5 \mathrm{ml}$. of culture medium with approximately 2,000 cells $/ \mathrm{ml}$. At the end of four days cell population was determined using a Coulter counter. This was roadily accomplished since the cells grow freely in the medium without attaching to glass. The number of cell generations that have occurred was plotted as a function of the logarithm of the concentration. of fluoride in the medium. By extrapolation the molarity of fluoride was determined which would result in a 20 per cent or a 50 per cent reduction in cell generation production ( $G d 20$ and $G d 50$ ).

Significant inhibition has not been found at a concentration of $3 \times 10^{-4} \mathrm{M} \mathrm{F}^{-}$(5-6 p.p.m. F-), and might possibly have been detected at $4.4 \times 10^{-4} \mathrm{M} \mathrm{F}^{-}(8-9$ p.p.m. F-). Growth depression was rapid from 5.9 $\times 10^{-4} \mathrm{M} \mathrm{F}$-, and was linear above a concentration of $10^{-3} \mathrm{M} \mathrm{F}^{-}$(19 p.p.m.) (Fig. 1). The amount of fluoride presumably required to inhibit the rate of cell reproduction by 20 per cent ( $G d 20$ ) was $1.1 \times 10^{-3} \mathrm{M} \mathrm{F}^{-}(20$ p.p.m.) (range $1.04-1 \cdot 13$ ) and by 50 per cent $(G d 50)$ was $1.5 \times 10^{-3} \mathrm{M} \mathrm{F}-(30$ p.p.m.) (range 1.38-2.04). It is apparent that much higher concentra. tions of fluoride were required to demonstrate growth inhibition in these mammalian cells than the $5.5 \times 10^{-5}$ MF- (1-1.2 p.p.m. F-) usually advocated for water fluoridation.

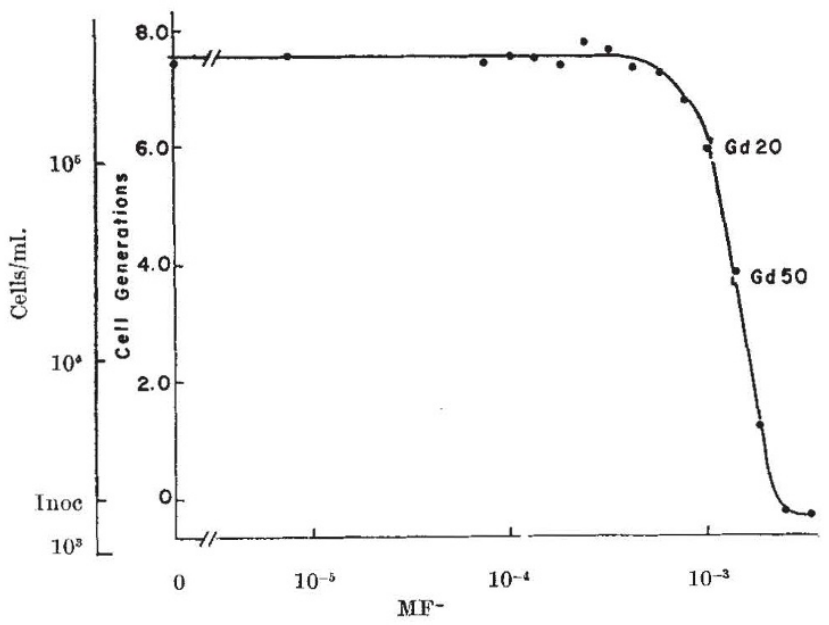

Fig. 1

These results differ from those reported by Berry ${ }^{2}$, who interpretod his data to indicate an effect on mammalian cells (strain $L$ mouse fibroblasts and HeLa $S-3_{\text {oxf }}$ cells) with a fluoride level of $0 \cdot 1$ p.p.m. $\left(5 \cdot 3 \times 10^{-6} \mathrm{M} \mathrm{F}^{-}\right)$.

Although the anti-caries effect resulting from the recommended 1-1.2 p.p.m. F- $\left(5 \cdot 3-6 \cdot 3 \times 10^{-5} \mathrm{M} \mathrm{F}^{-}\right)$in the water supply may very well be due to a local effect on the teeth ${ }^{3}$, the changes which occur in chronic fluorosis, such as mottling of the teeth and skeletal effects, are probably secondary to cellular dysfunction caused by toxic levels of fluoride in the immediate environment of the affected cell. This interference of cell function may be related to inhibitory effects of fluoride on specific enzyme systems, some of which are known to be affected by levels of fluoride which were found to inhibit the cells in the work recorded here $e^{4,5}$.

Water levels of fluoride differ from blood or tissue levels. Blood levels of fiuoride tend to be considerably lower than water levels and bone levels tend to be considerably higher ${ }^{6,7}$. Most of the fluoride in bone, however, appears to be bound with calcium as fluoroapatite and may not be physiologically active. Even so, it seems reasonable to assume that the effect on bones and teeth is related to the high concentration of fluoride in these structures and that pathological abnormalities occur when the level of ionized fluoride (which differs from total fluoride) rises above a critical level (affecting cell function). The kidney, which excretes fluoride, and therefore contains higher levels than other soft tissues, is the organ affected when the water-level is increased (approximately 125 p.p.m. in the water supply is required to cause pathological changes). This would indicate that, above a critical level of fluoride, cell function may be affected in the kidney as well as in bone ${ }^{8}$.

Other soft tissues do not demonstrate pathological changes except with an intake of excessive amounts of fluoride, and levels of fluoride in these tissues are below those required to affect the reproduction of the cells used in this work ${ }^{2}$.

An effect on any tissue, therefore, may depend on a sufficient level of fluoride in that tissue to affect cell function, although the critical level of fluoride necessary to produce an adverse effect may or may not differ in different tissues. This toxicity study is in agreement with those findings which indicate that $1-1 \cdot 2$ p.p.m. fluoride in the drinking water will produce no adverse effects.

This work was supported by U.S. Public Health Service grant $T I-A M$ 5416-01.

\section{JAMES A. AlBRIGHT}

Section of Orthopædic Surgery,

Yale University School of Medicine, 333 Cedar Street, New Haven, Conn.

${ }^{1}$ Fischer, G. A., and Sartorelli, A., Methods in Medical Research, 10 (Year Book Publishers, Chicago, 1964).

${ }^{2}$ Berry, R. J., and Trillwood, W., Brit. Med. J., 1064 (1963)

${ }^{3}$ Hartles, R. L., Proc. Nutr. Soc., 22, 97 (1963).

${ }^{4}$ Smith, Q. T., Armstrong, W. D., and Singer, L., Proc. Soc. Exp. Biol. and Med., 102, 170 (1959).

${ }^{5}$ Colowick, S. P., and Kaplan, N. O., Methods in Enzymology (Academic Press, New York).

' Singer, I., and Armstrong, W. D., J. App. Phys., 1, 5, 508 (1960),

7 Singh, A., and Jolly, S. S., Quart. J. Med., 30, 357 (1961).

${ }^{8}$ Hodge, H. C., Proc. Nutr. Soc., 22, 111 (1963).

'Largent, E. J., Fluorosis (Ohio State University Press, Columbus, 1961)

\section{Transfer of Melanin Granules from Melanocytes to the Cortical Cells of Human Hair}

THE manner by which the cortical cells of developing hair fibres acquire melanin pigment has been the subject of much speculation. Some authors have postulated that the pigment granules are actively inoculated into the prekeratinized cells by way of the dendritic processes of the melanocyte (cytocrine activity) ${ }^{1,2}$, whereas others have suggested that pigment granule transfer involves the active ingestion (phagocytosis) of the granules by the cortical cells ${ }^{3,4}$. Birbeck and Mercer ${ }^{3,4}$, who have found some evidence for this latter process, observed small 'pseudopods' enveloping the pigmented processes of black hair melanocytes at a point adjacent to the developing cortical cells of hair.

If the phagocytosis of pigment granules does indeed occur, then remnants of cell membranes ought to be apparent in the vicinity of the pigment granules in the cortex of mature hairs. That there is a close association 